\title{
PENURUNAN BAKTERI COLI PADA AIR SUNGAI MARTAPURA MENGGUNAKAN SARINGAN ARANG SEKAM PADI
}

\author{
Syarifudin A. \\ Poltekkes Kemenkes Banjarmasin Jurusan Kesehatan Lingkungan \\ Jl. H. Mistar Cokrokusumo No.1A Banjarbaru Kalimantan Selatan 70714 \\ Email: syarif_yazid@yahoo.com
}

\begin{abstract}
The Decrease in the Number of Coli Bacteria in Water of Martapura River Using The Husk Charcoal Filter. The habits of the people along the Martapura river, defecates into the river, causing the river water polluted by Coli bacteria that be able to cause disease. Water treatment is required to improve the water quality of the Martapura river, one of them is using "the husk charcoal filter " to obtain clean water that meets health requirements. This study aimed to analyze the effectiveness of the husk charcoal filter, and determine the thickness of the filter were most effective to decrease the number of coli bacteria in water of Martapura river. In this design, was performed the initial measurements (pretest), performed the treatment and performed the second measurement (posttest), so it could be seen the effectiveness of the treatment. The "husk charcoal filter" was effective to Decrease the Number of Coli Bacteria in the water of Martapura river as much as $69,2 \%$ $99,3 \%$. However, a decrease in the number of coli bacteria still above the standards required by the Water Quality Standard class B, after filtration. Because it still found much bacteria after filtering, it is advisable to boil water to boiling before consumption, because heating is the most effective way to kill microbial pathogens that be able to cause disease.
\end{abstract}

Keywords: Water of Martapura River; coli bacteria; the husk charcoal filter.

\begin{abstract}
Abstrak: Penurunan Bakteri Coli Pada Air Sungai Martapura Menggunakan Saringan Arang Sekam Padi. Kebiasaan masyarakat bantaran sungai Martapura membuang hajatnya ke sungai, menyebabkan air sungai tercemar bakteri Coli yang dapat menyebabkan penyakit. Untuk memperbaiki kualitas air sungai Martapura diperlukan pengolahan air, salah satunya menggunakan saringan arang sekam padi sehingga diadapatkan air bersih yang memenuhi syarat- syarat kesehatan. Penelitian ini bertujuan untuk menganalisis efektivitas saringan arang sekam padi, serta menentukan tingkat ketebalan saringan arang sekam padi yang paling efektif untuk menurunkan bakteri Coli pada air sungai Martapura. Penelitian ini memakai jenis penelitian eksperimental, dengan rancangan One Group Pretest Posttest Design. Rancangan ini dilakukan pengukuran pertama (Pretest) kemudian dikenakan perlakuan dan dilakukan pengukuran kedua (Posttest), sehingga dapat dilihat efektivitas perlakuan. Penyaringan air sungai Martapura dengan arang sekam padi efektif menurunkan bakteri Coli sebesar 69,2\% - 99,3\%. Namun penurunan bakteri Coli masih diatas angka standard yang dipersyaratkan Baku Mutu Air golongan B setelah dilakukan penyaringan. Mengingat masih terdapatnya bakteri setelah proses penyaringan disarankan sebelum dikonsumsi direbus sampai mendidh terlebih dahulu, sebab pemanasan merupakan cara yang paling efektif untuk mematikan mikroba patogen yang dapat menimbulkan penyakit.
\end{abstract}

Kata kunci: Air sungai Martapura; bakteri coli; saringan arang sekam padi.

\section{PENDAHULUAN}

Air sungai Martapura merupakan komponen lingkungan yang penting bagi kehidupan, selain sebagai penyusun tubuh mahluk hidup, air sungai Martapura juga digunakan masyarakat disekitar bantaran sungai dalam berbagai aktivitas, diantaranya untuk keperluan rumah tangga seperti mandi, cuci, memasak dan keperluan rumah tangga lainnya.

Air merupakan sumber daya yang sangat penting bagi kehidupan manusia, baik untuk dikonsumsi maupun 
digunakan untuk kepentingan lain. Namun, air bersih sangat sedikit persediaannya karena banyak sumber daya air tercemar [1].

Kebiasaan masyarakat membuang hajatnya ke sungai, menyebabkan air sungai tercemar bakteri Coli. Air yang mengandung bakteri golongan Coli dianggap telah terkontaminasi oleh kotoran manusia. Air yang dikomsumsi manusia mutlak tidak boleh mengandung bakteri patogen Bakteri Coli digunakan sebagai indikator dalam menentukan apakah air telah tercemar oleh tinja karena lebih tahan hidup pada kondisi lingkungan dibandingkan bakteri patogen lainnya.

Agar air yang masuk ke tubuh manusia tidak menyebabkan atau merupakan pembawa bibit penyakit maka diperlukan pengolahan [2].

Untuk memenuhi nilai baku mutu air yang ditetapkan diperlukan upaya pengolahan air dengan menggunakan saringan arang sekam padi yang merupakan salah satu alat penyaring yang digunakan dalam proses pengolahan air bersih. Arang sekam padi yang telah diaktivasi efektif dalam menghilangkan bakteriologis yang ada pada air baku. Pada proses penyaringan dengan saringan arang sekam, partikel-partikel tersuspensi dengan ukuran yang lebih besar dari pada pori-pori saringan akan tertahan di antara butiran-butiran arang sekam. Arang sekam padi sendiri memiliki kemampuan untuk menarik dan menempelkan partikel-partikel yang terdapat di dalam air pada permukaannya melalui mekanisme adsorpsi, sehingga partikel yang lebih kecil masih dimungkinkan untuk tertahan pada saringan. Disisi lain, bakteri golongan Coli juga ikut tersaring. Hal ini disebabkan karena bakteri golongan Coli didalam air sebagian besar hidupnya menempel pada partikelpartikel tersuspensi, dengan demikian bakteri golongan Coli juga ikut tersaring. Saringan arang sekam padi sangat cocok untuk komunitas skala kecil atau skala rumah tangga. Hal ini tidak lain karena debit air bersih yang dihasilkan relatif kecil [3].

\section{BAHAN DAN CARA PENELITIAN}

penelitian ini menggunakan jenis penelitian eksperimental, dengan rancangan One Group Pretest Posttest Design. Rancangan ini dilakukan pengukuran pertama (Pretest) kemudian dikenakan perlakuan dan dilakukan pengukuran kedua (Posttest), sehingga dapat dilihat perubahan-perubahan yang terjadi setelah adanya eksperimen [4].

Variabel yang diteliti terdiri dari bebas yaitu perlakuan saringan arang sekam padi berdasarkan perbedaan ketebalan saringan, dan sebagai variabel terikat adalah jumlah bakteri Coli.

Populasi adalah seluruh air sungai di bantaran sungai Martapura. Sedangkan sampel penelitian adalah sebagian yang diambil dari keseluruhan obyek yang diteliti dan dianggap mewakili seluruh populasi.

Alat yang digunakan terdiri dari Peralatan untuk pembuatan arang sekam padi, Peralatan desain saringan arang sekam padi terdiri dari pipa paralon diameter 4 inci, paralon $1 / 2$ inci, dop 4 inci, water moor, sok T dan sok L, gergaji besi, bor, serta lem plastik. Peralatan untuk pengambilan sampel air untuk sampel bakteriologis menggunakan botol sampel steril. Peralatan untuk pemeriksaan sampel air di Laboratorium secara bakteriologis terdiri dari tabung perbenihan, pipet ukur $10 \mathrm{ml}$ dan pipet ukur $1 \mathrm{ml}$, rak tabung perbenihan, inkubator. Bahan Penelitian terdiri dari Sampel air sungai Martapura dan arang sekam padi. Penelitian ini, dilakukan dengan tahapan sebagai berikut : Pembuatan tungku drum, Pembuatan cerobong asap dan penutup memakai sisa potongan bagian atas drum dengan kombinasi bahan seng dan lubang udara pada bagian bawah drum dibuat secukupnya. Perlakuan sekam padi untuk bahan baku. Proses dari pembakaran umpan sampai bahan baku terbakar dengan benar \pm 30 menit. Proses pengarangan biasa memerlukan waktu selama $\pm 2,5$ jam, dan temperatur pada waktu pengarangan berkisar antara $400^{\circ} \mathrm{C}$ $-600^{\circ} \mathrm{C}$. Apabila asap yang keluar sudah 
terlihat menipis putih atau bening kebirubiruan, lubang udara di bagian bawah tungku ditutup serapat mungkin dengan diberi pasir atau tanah. Untuk memulai proses pendinginan, di bagian cerobong asap ditutup dengan kain basah atau rumput yang rapat, sehingga tidak ada udara yang masuk ataupun keluar. Proses pendinginan arang pada tungku drum, memerlukan waktu rata-rata antara 4 - 5 jam dari awal penutupan. Aktivasi arang sekam padi dilakukan untuk memperoleh arang yang berpori dan luas permukaan yang besar dapat diperoleh dengan cara mengaktivasi arang sekam padi pada suhu $800^{\circ} \mathrm{C}$ selama 2 jam. Saringan arang sekam padi dibuat dari pipa paralon berukuran 4 inchi, untuk membuat saringan dengan ketebalan $40 \mathrm{~cm}$ memerlukan potongan pipa paralon sebanyak $60 \mathrm{~cm}$. Bagian bawah paralon diberi penyekat dengan jarak $10 \mathrm{~cm}$ menjorok kedalam. Pada bagian samping paralon diberi lobang sebesar 0.5 inchi dengan maksud untuk pemasangan pipa masuk dan keluarnya air dari saringan. Pipa paralon diisi dengan arang sekam padi yang telah diaktivasi sampai ketebalan $40 \mathrm{~cm}$ dengan cara dimampatkan sampai benar-benar padat, memerlukan arang sekam $1 \mathrm{~kg}$ berat kering kemudian dipasang sekat bagian atas $10 \mathrm{~cm}$ menjorok kedalam pipa. Pada bagian atas dan bawah poralon diberi tutup dengan maksud agar air yang disaring tidak merembes keluar. Demikian juga halnya dengan ketebalan saringan $60 \mathrm{~cm}$ memerlukan potongan pipa sebanyak $80 \mathrm{~cm}$, arang sekam padi $1,5 \mathrm{~kg}$ berat kering, sedangkan untuk ketebalan saringan $80 \mathrm{~cm}$ memerlukan potongan pipa sebanyak $100 \mathrm{~cm}$ dan arang sekam padi $2 \mathrm{~kg}$ berat kering. Sampel air diambil 1 meter dari permukaan air sungai Martapura, selanjutnya disebut air baku. Air sampel air dialirkan melalui Water Pump (pompa air) dengan debit 10 liter permenit diambil untuk dianalisa di laboratorium untuk mengetahui jumlah bakteri Coli memerlukan sampel air sebanyak $300 \mathrm{ml}$ untuk perlakuan sebelum pengolahan (sampel awal). Sampel Air sungai kemudian dialirkan melalui Water Pump (pompa air) kedalam saringan arang sekam padi pada variasi perlakuan yaitu pada media saringan ketebalan $40 \mathrm{~cm}, 60$ $\mathrm{cm}$, dan $80 \mathrm{~cm}$. Air sampel yang keluar dari saringan diambil untuk dianalisa di laboratorium untuk mengetahui jumlah bakteri Coli masing- masing memerlukan sampel air sebanyak 300 ml. Melakukan pemeriksaan kualitas air sungai sebelum diujicobakan terhadap jumlah bakteri golongan Coli. Penelitian dilakuan menggunakan saringan arang sekam padi dengan ketebalan $40 \mathrm{~cm}, 60 \mathrm{~cm}$, dan 80 $\mathrm{cm}$. Masing- masing tingkat ketebalan dilakukan uji labotorium dengan parameter pemeriksaan bakteri Coli sebagai hasil dari uji penelitian. Masingmasing perlakuan, dilakukan satu kali pengambilan sampling dengan reflikasi sebanyak 3 kali.

Untuk melihat efektifitas saringan arang sekam padi pada masing- masing perlakuan diperoleh dengan cara membandingkan hasil perlakuan dengan Permenkes RI No. 416/Menkes/Per/IX/ 1990 tentang Persyaratan Kualitas Air Bersih [5], sedangkan untuk mengetahui efektivitas antara ketebalan saringan yang digunakan dihitung terhadap penurunan jumlah bakteri Coli dalam satuan persen (\%), sedangkan untuk melihat perbedaan penurunan jumlah bakteri Coli terhadap tingkat ketebalan saringan pada masing masing perlakuan digunakan uji One Way Anova.

\section{HASIL PENELITIAN DAN PEMBAHASAN}

Hasil pengukuran debit aliran air sebelum perlakuan sebesar 0,17 liter/ detik (10,2 liter/menit), perlakuan ketebalan saringan $40 \mathrm{~cm}$ sebesar 0.03 liter/detik (1,8 liter/menit), ketebalan 60 $\mathrm{cm}$ sebesar 0,018 liter/detik (1,08 liter/ menit), sedangkan pada ketebalan $80 \mathrm{~cm}$ debit air keluar sebesar 0,012 liter/ perdetik $(0,72$ liter/menit). 
Tabel 1. Jumlah Bakteri golongan Coli/100 ml air sampel sungai Martapura

\begin{tabular}{ccccc}
\hline \multirow{2}{*}{ Replikasi } & Awal & \multicolumn{3}{c}{$\begin{array}{c}\text { Media Arang Sekam Padi } \\
\text { Ketebalan Media (cm) }\end{array}$} \\
& & 40 & 60 & 80 \\
\hline I & 24.000 & 9.200 & 790 & 140 \\
II & 16.000 & 5.400 & 1.300 & 170 \\
III & 24.000 & 5.400 & 460 & 110 \\
Rata-rata & 21.333 & 6.567 & 850 & 140 \\
Efektivitas (\%) & & 69,2 & 96,0 & 99,3 \\
\hline
\end{tabular}

Rata-rata bakteri Coli pada air sungai Martapura sangat tinggi yaitu 21.333 koloni per $100 \mathrm{ml}$ air. Perlakuan saringan menggunakan arang sekam memberikan efek penurunan bakteri Coli yang sangat besar hingga tersisa antara 140 hingga 6.567 koloni per $100 \mathrm{ml}$ air

Pada tabel diatas terlihat effektivitas penurunan bakteri Coli pada ketebalan $40 \mathrm{~cm}$ sebesar $69,2 \%$, dan ketebalan $60 \mathrm{~cm}$ sebesar 96,0 \%, sedangkan pada ketebalan $80 \mathrm{~cm}$ mengalami penurunan cukup besar yaitu 99,3\%.

Meskipun penurunan yang dihasilkan cukup besar namun persyaratan bakteri Coli untuk air bersih menurut Permenkes No. 416 tahun 1990 hanya 50 koloni per $100 \mathrm{ml}$ air. Ketiga variasi ketebalan saringan belum mampu memenuhi persyaratan tersebut sehingga perlu diestimasi ketebalan optimum agar jumlah bakteri yang tersisa memenuhi syarat.

Untuk menilai perbedaan rata-rata parameter yang diuji yaitu jumlah bakteri Coli digunakan uji anova satu arah. terdapat perbedaan nilai rata-rata masing-masing parameter berdasarkan variasi ketebalan saringan.

Uji LSD atau uji beda nyata terkecil merupakan lanjutan dari analisis varians (anova) yang bertujuan menentukan perbedaan secara statistik jumkah bakteri Coli berdasarkan variabel pengaruh (ketebalan filter). Misalnya antara $0 \mathrm{~cm}$ dengan $40 \mathrm{~cm}, 40 \mathrm{~cm}$ dengan $60 \mathrm{~cm}$ dan seterusnya hingga $60 \mathrm{~cm}$ dengan $80 \mathrm{~cm}$. Perbedaan hasil perlakuan tersebut ditentukan dari signifikansi parameter yang dibandingkan tersebut. Jika nilai signifikansi $<\alpha(5 \%)$ maka hasil perlakuan dinyatakan berbeda satu sama lain. (dalam tabel biasanya diberikan tanda bintang $(*)$ pada kolom beda ratarata (mean difference). Sebaliknya jika nilai signifikansi $>\alpha(5 \%)$ maka hasil perlakuan dinyatakan tidak berbeda secara statistik

Jumlah bakteri Coli pada masingmasing perlakuan terdapat satu perlakuan yang tidak berbeda secara statistik yaitu antara ketebalan $60 \mathrm{~cm}$ dan $80 \mathrm{~cm}$.

Secara statistik, penyaringan air menggunakan arang sekam padi mampu menurunkan parameter bakteri Coli perbedaan tersebut hanya terjadi hingga ketebalan $60 \mathrm{~cm}$ yaitu 850 koloni / 100 $\mathrm{ml}$ air. Penurunan yang terjadi pada ketebalan $80 \mathrm{~cm}$ yaitu 140 koloni / 100 $\mathrm{ml}$ dinilai tidak signifikan dan belum mencapai persyaratan menurut Permenkes No. 416 tahun 1990 golongan B untuk air bersih yaitu 50 koloni per 100 $\mathrm{ml}$ air. Untuk mencapai angka tersebut diperlukan estimasi matematis menggunakan persamaan regresi sebagai berikut: 


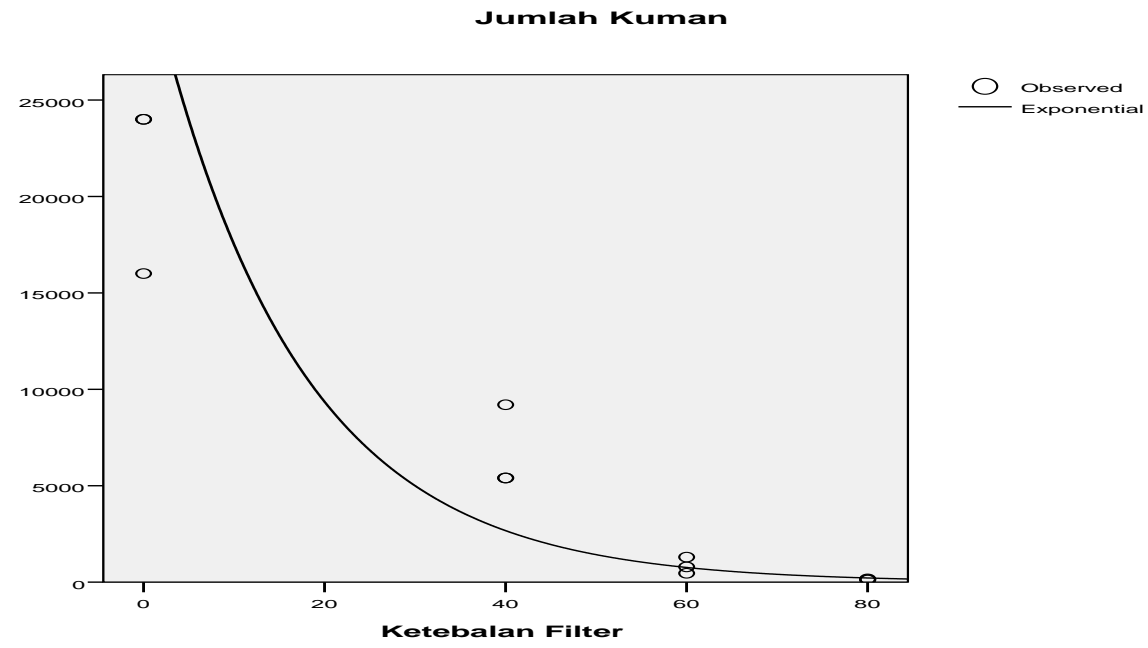

Gambar 1. Model Regresi untuk Bakteri Coli berdasarkan tingkat ketebalan saringan

Pada gambar terlihat penurunan bakteri Coli sangat curam pada awal perlakuan kemudian landai di akhirnya. Kurva penurunan nilai jumlah bakteri Coli dan ketebalan saringan membentuk pola eksponensial. Dari hasil perhitungan regresi menggunakan model eksponensial diperoleh nilai koefesien korelasi atau keeratan hubungan $(r)=0,95$ sehingga hubungannya sangat kuat, sedangkan koefesien determinasi $\left(\mathrm{r}^{2}\right)=0,902$ adalah besarnya konrtibusi ketebalan saringan yang diberikan untuk menerangkan variabilitas dari jumlah bakteri golongan Coli, artinya 90,2 \% bakteri Coli dipengaruhi oleh ketebalan saringan.

\begin{tabular}{|c|c|c|c|c|c|c|}
\hline \multicolumn{7}{|c|}{ Coefficients } \\
\hline & \multicolumn{2}{|c|}{$\begin{array}{c}\text { Unstandardized } \\
\text { Coefficients } \\
\end{array}$} & $\begin{array}{c}\text { Standardized } \\
\text { Coefficients }\end{array}$ & $\mathrm{t}$ & Sig. & \\
\hline & $\mathrm{B}$ & Std. Error & Beta & $\mathrm{B}$ & Std. Error & \\
\hline Ketebalan Filter &,- 063 & ,007 &,- 950 & $-9,582$ & & ,000 \\
\hline (Constant) & 32758,434 & 11538,525 & & 2,839 & & 018 \\
\hline
\end{tabular}

Model regresi yang dibentuk adalah $\ln y=\ln 32758,434-0,063 \mathrm{x}$ atau $\mathrm{x}$ $=\frac{\ln y-\ln 32758,434}{-0,063}$. Dengan menetapkan nilai y (nilai bakteri Coli) $=50$ koloni $/ 100$ $\mathrm{ml}$ sesuai dengan standar menurut baku mutu air golongan B untuk air bersih, maka diperoleh ketebalan optimal saringan $=103 \mathrm{~cm}$.

Hasil analisis statistik menunjukkan penyaringan air sungai Martapura menggunakan arang sekam padi dengan ketebalan yang bervariasi menghasilkan penurunan bakteriologis secara signifikan. Efektivitas penurunan bakteri Coli pada ketebalan $40 \mathrm{~cm}$ sebesar $69,2 \%$, artinya penyaringan dengan ketebalan $40 \mathrm{~cm}$ hanya mampu menurunkan bakteri Coli sebesar 69,2\% bila dibandingkan dengan sebelum perlakuan dan ketebalan $60 \mathrm{~cm}$ sebesar $96,0 \%$, juga mengalami penurunan bakteri Coli bila dibandingkan dengan sebelum perlakuan sedangkan pada ketebalan $80 \mathrm{~cm}$ mengalami penurunan cukup besar yaitu 99,3\%. Yang artinya 99,3 \% mampu menurunkan bakteri Coli bila dibandingkan dengan sebelum perlakuan. Namun ketiga variasi ketebalan untuk bakteri Coli belum memenuhi standar baku mutu air golongan B. Efek saringan terhadap penurunan jumlah bakteri Coli. 
Metode pengolahan air sungai Martapura dengan saringan arang sekam padi terbukti mampu menurunkan bakteri Coli bila dibandingkan dengan air sebelum pengolahan hal ini dapat dilihat dari hasil pengukuran bakteri Coli sebelum perlakuan sebesar 21.333 koloni / $100 \mathrm{ml}$, perlakuan dengan ketebalan 40 $\mathrm{cm}$ sebesar 5.400 koloni / $100 \mathrm{ml}$, ketebalan $60 \mathrm{~cm}$ sebesar 850 koloni / 100 $\mathrm{ml}$, sedangkan pada ketebalan $80 \mathrm{~cm}$ sebesar 140 koloni / $100 \mathrm{ml}$. Effektivitas penurunan bakteri Coli pada ketebalan 40 cm sebesar 69,2\%, dan ketebalan $60 \mathrm{~cm}$ sebesar 96,0 \%, sedangkan pada ketebalan $80 \mathrm{~cm}$ mengalami penurunan cukup besar yaitu 99,3 \%, meskipun belum memenuhi syarat kualitas air dengan ketebalan saringan $80 \mathrm{~cm}$ yaitu 140 koloni / $100 \mathrm{ml}$ (Lampiran 2 dan Lampiran 4), yang dipersyaratkan pada baku mutu air golongan $\mathrm{B}=50$ koloni / $100 \mathrm{ml}$. Dari model regresi diperkirakan ketebalan optimum untuk mencapai jumlah bakteri Coli sesuai persyaratan adalah $103 \mathrm{~cm}$.

Menurut Zubaidah, (2006) dalam penelitianya menyabutkan jumlah bakteri Coli air sungai Martapura sebelum dilakukan proses pengolahan pada alat floating water intake treatment diatas 2.400 coloni / $100 \mathrm{ml}$, sesudah dilakukan proses pengolahan pada alat floating water intake treatment terjadi penurunan jumlah bakteri Coli [6].

Penurunan Bakteri Coli oleh saringan arang sekam padi disebabkan oleh beberapa hal yaitu pori-pori yang dibentuk oleh butiran-butiran pada masing- masing ketebalan saringan menahan partikel-partikel yang terapung dan terlarut di dalam air. Partikel-partikel yang berukuran lebih kecil dari permukaan pori-pori dapat melewati media saringan. Penyebab lain adalah karena ketebalan media arang sekam padi yang digunakan, dimana semakin tebal media arang sekam padi, maka semakin banyak pori-pori yang terbentuk sehingga partikel- partikel di dalam air semakin sering kontak dengan poripori,akibatnya partikel-partikel tersebut tertahan dan menempel pada permukaan pori-pori. Dengan menempelnya partikelpartikel tersebut maka bakteri juga ikut tersaring, hal ini disebabkan karena keberadaan bakteri di dalam air sebagian besar menempel pada partikel- partikel zat padat tersebut, selain itu juga sel-sel bakteri mempunyai muatan negatif dan arang aktif mempunyai muatan positif. Semakin tebal saringan, bakteri Coli pada air sungai Martapura secara nyata menurun.

Menurut Hadiwiyoto (1981). Menempelnya bakteri pada partikel arang aktif karena sel- sel bakteri mengandung protein yang mempunyai gugus amino yang bermuatan negatif, sedangkan arang aktif mempunyai muatan positif. Dengan demikian adanya perbedaan muatan antara arang aktif dan bakteri akan terjadi penempelan bakteri pada arang aktif [7].

Bakteri golongan Coli pada air sungai martapura berasal dari kotoran manusia yang masuk kedalam aliran sungai. Keberadaan bakteri golongan Coli dipengaruhi oleh faktor kebiasaan masyarakat dibantaran sungai Martapura membuang hajatnya (tinja) disungai melalui jamban- jamban terapung. Bakteri Coli dihasilkan dari proses biologi yang dihasilkan dari proses buangan kotoran manusia kedalam sungai. Hal ini mengakibatkan air sungai Martapura tergolong sebagai air yang mempunyai cemaran bakteri yang cukup tinggi yaitu 21.333 koloni / $100 \mathrm{ml}$.

Perkembang biakan bakteri didalam air sangat dipengaruhi oleh suhu untuk kelangsungan hidupnya. Hasil uji suhu sebelum perlakuan berkisar antara $29^{\circ} \mathrm{C}-30^{\circ} \mathrm{C}$, hal ini menunjukkan bahwa kisaran suhu tersebut sangat baik untuk perkembangbiakan bakteri. Menurut Effendi (2003), kisaran suhu optimum bagi bakteri dan fitoplankton di perairan adalah $20-30^{\circ} \mathrm{C}$. Tinggi rendahnya suhu diperairan juga dipengaruhi oleh letak ketinggian dari permukaan laut, musim, cuaca, waktu, pengukuran, kedalaman air dan kegiatan manusia disekitarnya[7]. 


\begin{abstract}
KESIMPULAN DAN SARAN
Penyaringan air sungai Martapura dengan arang sekam padi efektif menurunkan bakteri Coli tetapi masih diatas angka standard yang dipersyaratkan Baku Mutu Air golongan B setelah dilakukan penyaringan.

Terdapat perbedaan efektivitas tingkat ketebalan saringan arang sekam padi dalam menurunkan jumlah bakteri Coli dan yang paling efektif pada ketebalan saringan $80 \mathrm{~cm}$.

Air hasil saringan sebelum dikonsumsi direbus sampai mendidh terlebih dahulu, sebab pemanasan merupakan cara yang paling efektif untuk mematikan mikroba patogen yang dapat menimbulkan penyakit.
\end{abstract}

\title{
KEPUSTAKAAN
}

1. Khiatuddin Maulida (2006) Melestarikan Sumber Daya Air dengan Teknologi Rawa Buatan. Gadjah Mada University Press. Yogyakarta.

2. Sugihrto. 1985. Penyediaan Air Bersih Bagi Masyarakat. Proyek Pengembangan Pendidikan Tenaga Sanitasi Pusat. Tanjungkarang.

3. Anonim (2009) Penjernihan Air Menggunakan Arang Sekam Padi http://iptek.net.id/

4. Notoatmodjo Soekidjo. 2002 Metode Penelitian Kesehatan.PT. Rineka Cipta. Jakarta.

5. Depkes, Rl. 1990. Peraturan Menteri Kesehatan RI Nomor 416/Menkes / Per/IX/1990 Tentang Syarat-syarat dan Pengawasan Kualitas Air. Jakarta.

6. ZubaidahTien dkk (2006) Aplikasi desain alat floating water intake treatment untuk perbaikan kualitas air sungai martapura. Resbinakes RI, poltekkes Banjarmasin. Banjarbaru.

7. Hadiwiyoto, S. 1981. Proses Mengikatnya Bakteri pada BendaPadat Almanak Nuklir Biologi dan Kimia, Pusat Nuklir, Biologi dan Kimia Angkatan Darat, Jakarta.

8. Effendi H (2003) Telaah Kualitas Air Bagi Pengelolaan Sumberdaya dan Lingkungan Perairan. Kanisius. Jakarta. 
